\title{
Lenguaje y retórica publicitaria
}

\author{
Magdalena García Toledo \\ Departamento Académico de Comunicación Social
}

\section{El problema de la investigación}

Ta investigación sobre la influencia de los Medios de Comunicación

@ Masiva y de la televisión en particular, ya ha determinado la significativa presencia de éstos en la vida moderna y su poderosa incidencia en la formación de la conciencia social y la movilización de la opinión pública. Los Medios se constituyen hoy en vehículos de información, entretenimiento y educación a nivel planetario.

En este sentido, la publicidad, sobre todo la televisiva, que viene absorbiendo la de los otros Medios por su gran poder de sugerencia y atracción para los públicos, es la que se erige en un paradigma de la propuesta transnacional de cultura que vivimos a través de la globalización económica, social y cultural, o mundialización como se le viene llamando.

Tan importante esfa publicidadi para ef tipo de televisión de origen norteamericano que tenemos, basado en los ratings de audiencia, que se habla de que la programación televisiva es sólo un pretexto para el verdadero fin de la televisión, cual es emitir publicidad. Así, ella viene a constituir un microcosmos de la cultura de consumo que se viene denunciando desde hace algunos decenios, aunque en el momento actual se han dejado de lado las supuestas intenciones perversas de los emisores y la pasividad aparente de los receptores, en pro de una actividad más comprometida dẹl lector en la interpretación de los mensajes. Con todo, se sigue aceptando la gran influencia socializadora y formadora por parte de los Medios y de la publicidad en particular.

La investigación sobre la publicidad reporta no sólo su gran presencia, constituyendo una ecología, que ha venido incrementándose en medidas nunca vistas, y que es consumida de manera inconsciente por el público. Se afirma que las personas ven, de una u otra manera, un promedio de mil avisos diarios, a 
través de los grandes medios de comunicación (prensa, radio y televisión), las nuevas tecnologías de la comunicación (TV por cable, TV interactiva, INTERNET, telemarketing), junto a las formas tradicionales, es decir, los murales, vallas, carteles, afiches, anuncios luminosos.

Las investigaciones constatan también la influencia decisiva de la publicidad en el modelamiento de la conciencia social, la creación y refuerzo de los valores, y las pautas de comportamiento social. La publicidad efectúa la reproducción social, a través de todas las estrategias de marketing, de ejecución de campañas, y de creación de mensajes, todas tareas perfectamente planificadas y ejecutadas con grandes inversiones y con procesos complejos y sistemáticos.

La publicidad televisiva, en concreto, se revela muy fuerte en cuanto a población total alcanzada (adultos y niños), en capacidad acumulativa y concentración de mensajes, estimulación emocional de las audiencias, capacidad de intrusión en los hogares, impacto de las marcas, eficacia de sus demostraciones, explotación de recursos para llamar la atención, y en la utilización del humor y el momento oportuno. Estos factores constituyen ventajas de la publicidad televisiva frente a los otros medios masivos, incluyendo a las nuevas tecnologías, no suficientemente explotadas por el sistema publicitario.

Uno de los factores más relevantes de Ta persuasión publicitaria, es el uso de un lenguaje específico, çuybjestatutores uno de los más acabados y sofisticados dentro de las estrategias expresivas, predicativas $y_{\text {r }}$ retóricas de que hace gala, implicando al receptor y construyendo sus mensajes a partir de investigaciones de mercado, que garanticen un perfecto conocimiento del usuario, del producto y de la competencia.

La aparente transparencia de este sistema, y su capacidad de "llegar" al público, sin embargo, encubren operaciones retóricas muy sofisticadas, cuyo análisis exhaustivo es necesario realizar para conocer la impecable eficacia de la publicidad, su poder de persuasión y su indudable influencia en las sociedades globalizadas del mundo moderno.

La investigación sobre el lenguaje y la retórica publicitaria, que da nombre a este artículo, llevada a cabo a lo largo de este año y como introducción a un estudio de largo aliento referido a la imagen de los públicos representados en la imagen publicitaria, partió entonces de las siguientes preguntas: ¿Cómo es el lenguaje de la publicidad televisiva? ¿Qué estrategias retóricas utiliza para cumplir sus fines? 


\section{El sistema publicitario}

La publicidad no es un medio de comunicación estrictamente hablando, sino el más importante soporte de los diferentes medios, de los cuales los masivos constituyen el fenómeno cultural de nuestra época. La publicidad es un sector económico, fuente importante de generación de recursos, y un sector social, un fenómeno cotidiano e inconsciente, con efectos a mediano y largo plazo y cambios lentos y sutiles, cuyo poder es la ubicuidad y la permanencia.

En ese sentido, es importante también reconocer que la publicidad, por sí sola, no es la panacea para incentivar el consumo o generar imagen. Es tan sólo una variable más de la mercadotecnia, y ninguna campaña, por eficiente que sea, alcanzará los objetivos corporativos que se persigan, si el producto o servicio no satisface plenamente a su mercado meta, o el precio, los canales de distribución o el servicio, no están acordes a los requerimientos y demandas del mercado

La publicidad siempre ha existido. Las inscripciones en las plazas públicas, los pregoneros, las insignias, los avisos, la publicidad artesanal del siglo XIX con técnicas calcográficas y xilográficas que dan un gran valor testimonial de la época, y otras formas tradicionales, existen desde tiempos lejanos. Sin embargo, sólo con la Revolución Industrial la publicidad ha adquirido la importancia que hoy tiene. Podría decirse que vivimos rodeados de publicidad, gran parte de las imágenes que observamos se refieren directa o indirectāmentea ella.

La publicidad televisiva ha llegado a su estado actual hace aproximadamente 50 años y uno de los factores que contribuyeron a ello fue la producción en masa de bienes y el desarrollo de la industria cultural.

Publicidad es pues una forma de comunicación persuasiva, encaminada a provocar la apetencia del producto. Contrariamente a los medios de comunicación masiva que declaran explícitamente sus fines informativos, educativos y culturales (aunque la realidad sea otra cosa), la publicidad es el único sistema que reconoce la ganancia como objetivo último. Y en este sentido, todos los procedimientos y técnicas que emplea, están dirigidos a este fin.

La tremenda competencia originada por una producción que rebasa ampliamente la demanda, ha permitido que la publicidad se desarrolle como lo ha hecho a partir del aporte de la investigación científica, sobre todo de la psicología, y principalmente de una inversión astronómica que, en algunos casos, su- 
pera a la deuda externa de algunos países subdesarrollados. Este desarrollo continuará en el futuro, amenazando la autonomía cultural de estos países, a través de una transnacionalización creciente que envuelve además el campo de la informática y las nuevas tecnologías.

De otro lado, podemos decir que el modelo estímulo-respuesta-reforzamiento del conductismo, algunos principios gestálticos y el conocimiento del inconsciente que aporta el psicoanálisis, son las fuentes que nutren las diferentes estrategias persuasivas y expresivas de la publicidad.

Hay una posición de defensa que considera a la publicidad como una de las formas más importantes de comunicación, que informa y orienta al consumidor, promueve el desarrollo económico porque crea mayor demanda, facili-ta la competencia y baja el precio de los productos, ya que al producirse una mayor demanda, la producción se realiza en masa. Asimismo, indican que eleva el nivel de vida, contribuye a la satisfacción del consumidor, facilita la existencia de los medios de comunicación, y además, gracias a la publicidad se economiza tiempo porque permite saber quién y dónde se ofrecen las cosas.

Por otro lado, se encuentran los detractores de la publicidad, que la toman como un elemento negativo, es decir consideran que es la causa de la aparición de nuevas necesidades. Señalan que la publicidad confunde al consumidor porque le presenta mụchàsmarcas. creanecesidades imprácticas, presiona y manipula, incluşo a yeces con mal gusto y poca delicadeza. También dicen que promueve la sociedad de consumo creando insatisfacción, pues siempre se deseará algo nuevo. Emplea falsas aseveraciones, ya que en muchos casos se dicen cosas que no son ciertas. Impone el mito de un orden social benefactor y de felicidad plena para los seres humanos.

$\mathrm{Al}$ respecto, cabe deducir que aunque algunos censuren los efectos publicitarios y otros le atribuyan condiciones positivas, lo cierto es que la publicidad influye en el destinatario y juega un importante papel en la formación de valores $\mathrm{y}$ estereotipos sociales.

A pesar de la semejanza de los deseos humanos, las diferencias entre distintas culturas aún persisten, es por eso que el conocimiento de los elementos culturales únicos de cada grupo tiene una gran importancia en el diseño y eficacia de cualquier estrategia de comunicación. La cultura se configura así como un elemento clave del procesamiento de la información publicitaria, una 
variable moderadora de naturaleza global y, por tanto, del éxito de la comunicación.

Haciendo referencia a la revolución tecnológica del siglo XXI, vemos que los cambios del futuro no sólo se encuentran en la computación, la fibra óptica, la superpista de la información, la multimedia, la interactividad, sino también en las propias creencias que deberán sufrir profundas reestructuraciones para enfrentar el dos mil, no sólo en función de ellas, sino para un consumidor distinto y activo que ya es a la vez parte del mundo global y personaje único de este planeta.

Es en los Estados Unidos y en los países más ricos donde la publicidad se desarrolla de una manera impresionante, a través de poderosas agencias que se van convirtiendo en empresas multinacionales, mega-agencias, y grupos de comunicación global que controlan los sistemas nacionales de comunicación de los países en desarrollo. La sociedad de consumo encuentra su explicación en esta suerte de "ideología" de la publicidad, donde la felicidad del ser humano sólo se encuentra en el consumo de los productos y servicios que nuestra moderna sociedad industrial nos propone. Un examen atento de nuestra televisión local podría confirmar estas aserciones, así como el surgimiento y rápido apogeo de profesiones ligadas al campo de la publicidad y el marketing.

En América Latina se observa una arremetida publicitaria que parece contradictoria con los niveles de pauperización que viene sufriendo la población por la crisis generalizada que yive el continente y las políticas neoliberales que se vienen implementando, una de las cuales es la apertura sin condiciones de los mercados para la inversión extranjera y la importación de productos sobre todo norteamericanos.

Simultáneamente con la globalización, la segmentación de públicos será cada vez más exigente, la competencia más agresiva, y la capacitación y la actuación imprescindibles. La publicidad, por su naturaleza global y totalizadora, se sitúa con perfecta naturalidad en este contexto.

Así pues, la función de la publicidad no es exclusivamente económica, sino también simbólica, al actuar como un medio de reproducción social. En este sentido, los medios y la publicidad son instrumentos que catalizan y generan los sistemas de mediación social, que se reproducen y estructuran lingüísticamente constituyendo uno de los escenarios donde se produce y desarrolla la comunicación social. 
La complejidad actual de la actividad publicitaria exige la presencia de las agencias, encargadas sobre todo de dos funciones principales: la investigación del mercado publicitario, vale decir de los segmentos del público, y la producción de mensajes. Ambas son fases importantes de la campaña publicitaria, juntamente con una planificación cuidadosa que busca crear un impacto que asegure la notoriedad del producto y el mantenimiento constante del favor del público. Uno de los factores para lograr ese impacto es el posicionamiento del producto, que no es más que la búsqueda minuciosa del factor único y especial que distinga el producto de cualquier otro de la competencia, que considere a la marca como "el héroe del anuncio", y que se dirija a la satisfacción real o imaginaria de una necesidad.

\section{El mensaje publicitario}

Comúnmente se conceptúa el mensaje como la idea, opinión, concepto o sentimiento que se quiere manifestar. El mensaje publicitario es más que eso. Es un texto, un conjunto de signos y códigos estructurados en una unidad, que para fines de análisis, podemos descomponer en sus elementos pero sin olvidar que constituyen una totalidad. Así, se habla del mensaje televisivo como de una línea que concluye en un significado, siendo más bien como un tejido donde se encuentran entrelazados mensajes -principales y secundarios, directos o indirectos, denotativos y connhotativosera través delunsconjunto de signos de diferente naturaleza.

"Jorge Puccinelli Converso»

El mensaje publicitario puede concebirse como una forma elemental de conocimiento relevante de ámbito colectivo y tendencioso en los criterios transmitidos, que aunque se refiera a un conocimiento comercial determinado y se realice en un espacio físico muy limitado y en un periodo temporal breve, actúa como un elemento de partida para el ritual y la rutina diaria del comprador tratando de inducir actitudes positivas e intenciones de compra.

La mayoría de creativos publicitarios está de acuerdo en que el mensaje debe reunir una serie de requisitos que deben ser cumplidos si se quiere que lleguen a la audiencia. Entre esos requisitos se mencionan: comprensión del mensaje, que debe ser suficientemente sencillo como para poder ser entendido por la mayor cantidad de receptores; atracción, dada por la simplicidad del mensaje que no se contrapone a la originalidad, como uno de los recursos de captación de la atención; credibilidad y autoridad para ser tomado en serio; y persua- 
sión, o capacidad de sugestión del mensaje que debe convencer al público de las innegables ventajas del producto.

También los teóricos publicitarios están de acuerdo en que el mensaje de la publicidad debe reunir ciertas características:

- simplificación del mensaje o capacidad de ser entendido rápido y fácilmente,

- concreción de los temas que deben pertenecer al mundo concreto del público, ser familiares a él,

- susceptible de ser repetido y retenido por cualquiera,

- carga emocional, por la cual el mensaje debe suscitar la movilización del deseo y la identificación.

Las características anotadas anteriormente, se condensan en el eslogan, recurso estratégico de la publicidad, que viene a ser una frase u oración breve, clara, concisa y repetible. Es el mensaje lingüístico esencial, que acompaña a la imagen cinética (televisión, cine, videó) y estática (cartel, página publicitaria) o es la oralidad propia del "spot" radial.

Los elementos del mensaje publicitario televisivo tienen en cuenta dos grandes componentes:

\section{A. La palabra}

\section{Biblioteca de Letras}

En la publicidad moderna, la imagen no es un simple acompañante de la palabra, un recurso ilustrativo o decorativo, sino que ella cumple una importante función informativa, tan es así que a veces encontramos imágenes publicitarias casi desprovistas de texto. Las funciones que cumple la palabra frente a la imagen toma en cuenta:

- el anclaje, en el cual la palabra, como lo evidencia el concepto, precisa, fija, "ancla" el significado de la imagen, al reducir su extensa polisemia,

- el relevo, sobre todo en los mensajes con predominio narrativo -como aquéllos que se presentan en el lenguaje de la historieta-, la palabra da paso a la imagen y viceversa;

- la complementación, imagen y palabra aportan ambas su propia información, globalizándola en el mensaje publicitario, 
- la retórica, la palabra establece similitudes, comparaciones, metáforas, hipérboles, antítesis... En general se organiza en figuras "literarias", así como en artificios como juegos de palabras, paradojas y otras;

- la redundancia, la palabra verbaliza el contenido de la imagen, para asegurar principalmente la inteligibilidad.

En el anuncio publicitario, la palabra se presenta en diferentes formas: como título y subtítulo, en forma interrogativa o imperativa. El argumento es el cuerpo central conformado por textos narrativos, descriptivos, informativos, testimoniales, humorísticos, en verso, etc. La argumentación puede ser racional, emotiva o mixta.

Estos componentes del texto escrito se disponen gráficamente a través de ciertos espacios, tipos de letras y signos, que por su tamaño, color y forma pueden ser analizados en los niveles denotativo y connotativo.

\section{B. La imagen}

La imagen publicitaria es fundamentalmente fática e implicativa, busca el impacto perceptivo, y para ello se vale de la hiperbolización del tamaño, ángu-lo, color, iluminación, nitidez y contraste de la imagen. Todo este esfuerzo redundante está dirigido a llamar la atención y māntenerla aunque sea por breves segundos. Pero a la publicidad también le interesa asegurar la lectura del significado, $y$ en este sentido, la estrategia retórica tiene un papel importante que cumplir.

El color es esencialmente una categoría psicológica que busca suscitar la atención y despertar emociones, hacer la realidad más "objetiva" y favorecer la asociación entre lo presentado en el anuncio y lo presentado en el punto de venta. Cuando el consumidor tiene una alta motivación para procesar el anuncio, el color puede tener un doble efecto sobre las actitudes hacia el producto. El color puede exaltar o calmar, refrescar, ser misterioso, exótico o puro; además, el color da forma a las percepciones de los objetos del mundo.

La fuente es la persona que avala y muestra el producto, es decir uno de los emisores del mensaje publicitario: un personaje conocido por el público, un especialista, un cliente satisfecho, un animador o locutor, casi siempre de la televisión. La fuente puede ser utilizada para aumentar la atención y el recuerdo del anuncio, para propiciar el cambio de actitudes positivas hacia una empresa y 
sus productos, o también para lograr la asociación de la personalidad del emisor con la imagen del producto.

La producción de mensajes publicitarios es la fase en la cual los especialistas diseñan y producen los mensajes (mensajes-tácticos) para los diversos $\mathrm{Me}$ dios de Comunicación seleccionados. Esto conlleva, como hemos dicho, un profundo conocimiento de sus técnicas y lenguajes, así como de las estrategias persuasivas. El proceso de creación y producción contempla tres aspectos: el eje estratégico, es decir el trabajo de investigación psico-sociológico, el concepto comunicativo o estrategia de mediación para conseguir el efecto deseado y el relato publicitario, concreción del trabajo de creación, cuya propuesta se somete a pre-test.

La persuasión se encuentra en la base de todo el mensaje publicitario. Regla de oro de la publicidad, traduce los deseos que existen en el interior de las personas para reflejarlos y lograr la identificación con una marca o un producto. La persuasión publicitaria usa muchas veces, integrándolas, tanto la argumentación racional como la aplicación de recursos emocionales y el prestigio como atractivo para el consumidor.

Son tres las necesidades persuasivas, sobre las que se construyen los mensajes: necesidad objetiva de hacer conocido-deseado el producto; necesidad de vincular el producto con una motivaciōn pertinente, fundada en una carencia que afecta a amplios sectores del público (deseos y aspiraciones profundas); y, necesidad de motivar (además de la compra) la recepción del anuncio, haciéndolo atractivo, grato, fácil de digerir y generador de una satisfacción estética.

\section{El lenguaje publicitario}

Un lenguaje se estructura en una situación de comunicación donde hay un mensaje que se quiere transmitir con una intención conciente o inconsciente, explícita o implícita, entre un emisor y un receptor. El lenguaje publicitario cumple con el fin de representar y traducir una realidad, la realidad cotidiana, reflejo del decir, del hacer y del ser del hombre. El lenguaje publicitario cumple las tres funciones básicas del lenguaje común: descriptiva como información, expresiva como sugestión, e indicativa como persuasión.

Los autores que analizan la publicidad desde el punto de vista lingüístico distinguen en este lenguaje el sustantivo como objeto (el ser), el adjetivo como 
cualidad del objeto (la razón del ser) y el verbo como acción del objeto (eje triangular del ser).

El sustantivo tiene como objetivo nombrar las cosas que, en la publicidad, está constituido por la marca o nombre del producto; cumple una función denominativa, al otorgar identidad a los productos, suscitando un efecto de reconocimiento y memorización, centrando la función cognitiva.

$\mathrm{El}$ adjetivo crea una personalidad a través de los atributos que confiere a los productos publicitarios. La función exaltativa y exultativa de sus manifestaciones posiciona a aquéllos en la mente de los consumidores, a través de la función emotiva y la apelación implícita al consumidor para atraerlo, sensibilizarlo y crear un vínculo entre el emisor como sujeto creíble y fiable, y los consumidores como sujetos con necesidades y aspiraciones a satisfacer.

El verbo es la acción que cumplen los productos y por otra parte el que con tono imperativo estereotipa, en su generalidad, el venga, compra, vea, pida, exija, consuma, beba, oiga, cambie, visite, haga y tenga de los mandatos publicitarios.

La esencia misma del lenguaje publicitario son la denominación y la predicación como funciones nucleares.

\section{Biblioteca de Letras \\ Géneros publicitariơ «orge Puccinelli Converso»}

Los géneros publicitarios dan lugar a dos grandes tipos de publicidad:

- Informativa, denotativa u objetiva, con función referencial, cuyo objetivo es entregar datos que informen al futuro usuario de las reales características o beneficios del producto o servicio. La publicidad médica o gubernamental sobre servicios de salud es ejemplo de este tipo de publicidad.

- Motivacional, connotativa o subjetiva, con función expresiva o conativa, cuyo objetivo es actualizar o crear una necesidad relacionando ésta con el consumo. Es rica en significados inferidos, juega mucho con las emociones, intenta crear imágenes que se posicionen en la mente de los consumidores, apela a las motivaciones más profundas del ser humano, como aquellas relacionadas al sexo, el alimento, el abrigo y a las necesidades de seguridad, afirmación y realización. Esta es la publicidad que nos interesa para el análisis crítico. 
Una clasificación por funciones más precisa de la publicidad es la que sigue:

- Presentación de un producto. Son los mensajes destinados a presentar un producto o un servicio nuevo; es usual la amplificación del producto, en primer plano; a nivel escritural se enfatizan las palabras «nuevo», «presenta», «ahora».

- Demostración de cualidades o beneficios. Son los mensajes donde se «demuestra» los probables efectos benéficos que traerá el uso de determinado producto. Es el caso de los detergentes que dejan la ropa «blanquísima».

- Solución de un problema. Aquí se presentan diferentes tipos de conflictos y se presentan las soluciones a través del uso de productos o servicios. Ejemplo: los shampoos contra la caspa o los desodorantes.

- Concursos. En ellos se ofrecen recompensas en bienes, dinero o viajes. Ejemplo: juntando tantas chapitas o epvolturas se ganan tales premios.

- Testimonios. Muestran personajes famosos usando productos e incitando a la imitación; su eficacia se funda en la autoridad y prestigio de los mismos. Son estrellas de la TV y el cine, deportistas, periodistas, y en general figuras públicas, que prestan sy imagen para ese propósito.

- Lúdicos. Utilizą efectos visuales y sonoros para, entre otros efectos, entretener a la audiencia y ayudarla a la memorización del mensaje. Los niños y los jóvenes son la audiencia preferente de este género de publicidad.

\section{Los elementos del lenguaje publicitario televisivo}

1. El sistema visual. El referente del sistema visual es la realidad misma, es decir todo lo que es perceptible por los sentidos. En la realidad, encontramos a las personas, el mundo animal y vegetal, la naturaleza, los objetos naturales y artificiales. Es el hombre el sujeto principal de la realidad. Los ángulos de estudio del hombre son su dimensión física, psíquica y social, y las relaciones consigo mismo.

La imagen visual es concreta, aunque se refiera a algo abstracto, siempre vemos algo preciso y particular. En el ser humano, por ejemplo, su mundo psíquico lo podemos deducir de sus gestos y expresiones faciales, el movimiento de sus manos y cuerpo, la postura, lo que dice y cómo lo dice, sus silencios. 
La otra dimensión del sistema visual es la imagen gráfica, los dibujos e ilustraciones, los mapas, diagramas y diseños. En ella podemos analizar la topografía, es decir la organización espacial, y la tipografía, como el estudio de las formas, tamaños, orden y color de las letras.

La kinésica es el estudio del movimiento, a través de la mímica, la danza, y el movimiento en general. Un papel especial tiene el estudio de la mirada y los movimientos de la mano.

La proxémica es el estudio del empleo que se hace del espacio en el que el hombre actúa. Destaca el papel de las distancias como indicadores del status social y del tiempo. Los significados son diferentes cuando las distancias son intimas, personales, sociales y públicas.

La puesta en escena es la articulación de todos los elementos visuales en un espacio-tiempo, manifestándosè en una situación o un hecho. Los elementos visuales -recordemos- son los sujetos (personas, animales, objetos) y sus dimensiones: protagonistas, presentadores, loeutores; el ambiente o escenografía donde actúan, la luz, el color, la profundidad de campo, el ángulo, la palabra, los gestos, la música, los sonidos y ruídos, el movimiento. Toda esa referencia de la realidad se organiza en la imagen visual, adquiriendo una nueva significación que no tenía en la realidad primigenia. Por eso la imagen visual es un nuevo signo, un símbolo, una forma de crear sentido.

Biblioteca de Letras

2. El sistema sonoror Sus componenentessoin la palabra, la música, los ruidos, sonidos y el silencio.

La palabra es el elemento más plástico de la comunicación sonora. En la palabra podemos distinguir el sistema lingüístico, lo que se dice; y el sistema paralingüístico, cómo lo dice, a partir de la intensidad, duración, timbre y tono.

Su característica fundamental es que sea audible, en otras palabras, que sea clara, bien pronunciada, con la cadencia y ritmo acorde a las normas de habla de la comunidad. La locución es la expresión más común. Ella asume el to-no de una conversación informal, cálida, natural y comunicativa. Aunque la publicidad se dirige a una masa en términos de recepción, en realidad es un medio personal intimista.

La calidad de los micrófonos y de la consola de sonido ayudan a que la voz tenga todas las características "fonogénicas" que venimos mencionando. 
La música cumple una variedad de funciones dentro del lenguaje audiovisual: identifica el programa, acompaña las locuciones y presentación del producto; separa las secuencias, diálogos y escenas; crea diferentes ambientes; caracteriza personajes y hechos; y provee información. Un programa sobre salsa, por ejemplo, o música negroide o jazz convierte a la música en un documento en sí mismo.

Los ruidos y sonidos son como la música, elementos fundamentales del lenguaje audiovisual y cumplen, como la música, las mismas funciones anotadas anteriormente.

El silencio, en términos de producción audiovisual es interpretado como un "bache", como un defecto técnico. Sin embargo, el silencio es un recurso que contribuye a crear significación en un mensaje; no es ausencia pues de sonido, sino que está cargado de tensión y sentido.

3. El sistema gramatical, Está en construcción permanente y no es algo rígido y de valores universales, depende mucho de la obra televisiva en particular. Conlleva dos operaciones fundamentales: selección de los fragmentos de la realidad que se van a reproducir; y combinación de imágenes y sonidos para crear una obra nueva.

Para llevar a cabĐéstasioperacioneş existertmúltiples recursos y procedimientos para la creatividad propiamente dicha así como para el manejo de la tecnología.

Los elementos de la gramática audiovisual son el plano como registro ininterrumpido que realiza la cámara de una situación o hecho. Se trata de una porción de cinta magnética donde se graban imágenes y sonidos captados entre la puesta en marcha de la cámara o de la grabadora y el de su terminación. En el plano se estudian el recuadro, la dimensión, la duración, el ángulo, la composición, la profundidad de campo y la iluminación.

Otro elemento es el ángulo, clasificado en normal u horizontal, al nivel de los ojos; el ángulo en picado, cuando vemos al personaje desde arriba: en términos generales significa aplastamiento, insignificancia; y el ángulo en contrapicado, cuando lo vemos desde abajo da la impresión contraria a la anterior, es decir, amenaza, pompa. 
La composición es la organización en el plano, de los sujetos y objetos representados, buscando efectos de armonía, unidad y comprensión del mensaje; debe analizar la posición del sujeto en la imagen, las líneas dominantes y la claridad. Debido a la movilidad de la imagen, la composición en televisión es cambiante.

La profundidad de campo, determinada por la iluminación y el foco, nos da la sensación de que los elementos del plano se encuentran a diferentes distancias respecto del fondo, es decir, en perspectiva.

Hay otros elementos de la gramática publicitaria que sería muy extenso desarrollar aquí. Baste saber que hacen de la imagen un lenguaje específico y nada simplista.

\section{La retórica publicitaria}

La función persuasiva es propia del điscurso codificado por las retóricas. En la antigüedad, la retórica era la argumentación, es decir una serie de artificios que daban al discurso un carácter original, revelando información inesperada y por tanto eficaz para los propósitos de la comunicación. Entre esos artificios, se cuentan las figuras retóricas, y dentro de ellas la metáfora y la metonimia como las más importantes dẹtro dẹlậpublicidad. Eltas aenfiguran las relaciones paradigmáticas y sintagmáticasrespectivamente en ląçonstrucción del significado.

A pesar de que la publicidad no es un fenómeno exclusivamente retórico, sino interdisciplinario en el que entran muchas ramas del saber y del hacer, su tratamiento es obligado ya que no sólo a través de él se dota de nuevos significados a la realidad en base a la utilización de un doble plano, el real y el figurado, sino también se realiza una importante función del sistema publicitario: la persuasión.

De la retórica, más que sus posibilidades estéticas, interesan las potencialidades comunicativas. Sin pretender ahondar en las diversas tipologías de "figuras" retóricas, detallamos a continuación las más usadas en la publicidad:

1. La esencia. El producto se presenta solo, con la autoridad y dignidad que le da su posición en la imagen, casi siempre en primer plano, bien iluminado, 
con un fondo que no compita con él, con un color y nitidez que lo distingan, en un monopolio del espacio que deja casi ausenta la palabra. No hay presentador, argumento, decoración, a veces ni slogan, que distraigan la concentración de la mirada en el producto.

2. La metáfora. Es el recurso retórico por excelencia de la publicidad, en el cual un hecho o un objeto es presentado como metáfora de un producto. Con esto se añade un valor determinado a la imagen. El análisis debe desentrañar si realmente estos valores se corresponden a los beneficios o características de los productos.

La metáfora estimula, desde su dominio natural, el juego comparativo, las sustancias adjetivas de la imagen y la palabra más en su simbolismo que en su literalidad, entre lo enunciable y lo anunciable.

La función más evidente del lenguaje publicitario, convencer, perdería fuerza sin el canto glorificador de la metáfora, a cuya influencia el lenguaje publicitario debe que a veces se le considere un metalenguaje.

Por lo tanto, puede decirse que el lenguaje poético de la metáfora se transfiere, en gran parte, al de la publicidad, que quiere ser, como el de la poesía, el lenguaje del placer.

La operación metafórica consiste en la traslación del significado de una imagen a otra, de tal manera que ilustra eficazmente fo que la publicidad quiere significar: "si usas el humeetante X, tu cutis sera como el de una rosa". Este es un ejemplo muy elemental pero claro de metáfora visual.

3. La Sinécdoque. Es una forma de la metonimia, por la cual se expresa el más por el menor, el todo por la parte. La sinécdoque es la selección pertinente de una parte o rasgo del producto, realizando la connotación y donde el lector completa el sentido global del mensaje a partir de esa selección. Una mano sofisticada con un brazalete de diamantes sosteniendo un exquisito vaso de licor, está representando fuertemente el mundo elegante y sofisticado del consumo y a una clase social determinada.

4. La Metonimia. Es una figura típica del relato que permite transferencias asociativas de una realidad a otra y que exige al lector completar la historia a partir de elementos concretos. Por ejemplo la imagen de un dormitorio donde se ve en primer término una camisa masculina, se escucha música sensual y voces 
en «off» susurrando y riendo (no se ven los personajes), permiten «continuar» la historia, connotando inmediatamente el producto camisa. Ejemplos como éste los encontramos con mucha frecuencia en la publicidad televisiva, donde el movimiento permite desarrollar los relatos.

Estamos pues ante la presencia de un recurso mediante el cual se nombra la realidad de una manera diferente, se representa el todo por una parte o viceversa.

Lo importante es que la selección de una metonimia determina cómo construimos el resto del hecho a partir de la imagen. Este es un trabajo típico de los signos-índice que nos remiten de una cosa a otra, y el trabajo típico de la publicidad. Por eso es un recurso poderoso que hace aparecer lo mostrado por los Medios como lo real y verdadero.

\section{El método en la investigación publicitaria}

Volviendo a la investigación que mencionábamos al comienzo del artículo y después de un desarrollo teórico que contextualiza nuestro trabajo, trabajamos con una muestra de 80 spots televisivos registrados durante la primera semana de abril del año en curso Sé usó una guía de análisis que tomó en cuenta las siguientes variables: publicidad informativa y connotativa, público destinatario, géneros y recurßoş usåådomotivaciōnesta las que se apela, temas e historias, tratamiento de personajes estrategias de implicación del receptor, tipos de planos, ángulos, movimientos de cámara y edición, música característica, color, locución, eslóganes.

\section{Análisis de los resultados}

Presentamos a continuación, a través de cuadros, algunos de los resultados obtenidos, centrándonos principalmente en las categorías específicas referidas al lenguaje y retórica publicitarios. El análisis que obviamos, por falta de espacio, se resume en el último acápite de este informe, referido a las conclusiones. 
CUADRO $N^{\circ} 1$

REGÍMENES PUBLICITARIOS

\begin{tabular}{|l|c|c|}
\hline Publicidad informativa & 23 & $29 \%$ \\
\hline Publicidad connotativa & 57 & $71 \%$ \\
\hline
\end{tabular}

\section{CUADRON ${ }^{\circ} 2$}

GÉNEROS PUBLICITARIOS

\begin{tabular}{|c|c|c|}
\hline Demostración beneficios & 25 & $33 \%$ \\
\hline Historias de vida & 21 & $28 \%$ \\
\hline Solución de problemas & 9 & $12 \%$ \\
\hline Documentales & 7 & $9 \%$ \\
\hline Testimonios & 4 & $5 \%$ \\
\hline Presentación producto & 4 & $5 \%$ \\
\hline Concursos, canjeseca d & Ietr & $5 \%$ \\
\hline Dibujos animados cémics & Coliver & $2 \%$ \\
\hline
\end{tabular}

\section{CUADRON 3}

TENDENCIAS FORMALES EN LA PUBLICIDAD

Planos generales de imagen Angulos de cámara normales Cámara de movimiento normal Cámara fija, en trípode Edición tipo corte Locución masculina

\begin{tabular}{|l|l|}
\hline 43 & $32 \%$ \\
64 & $89 \%$ \\
63 & $93 \%$ \\
65 & $90 \%$ \\
69 & $97 \%$ \\
50 & $86 \%$ \\
\hline
\end{tabular}


CUADRON ${ }^{\circ} 4$

IMPLICACIÓN DEL RECEPTOR

\begin{tabular}{|l|r|r|}
\hline No se habla directo a la audiencia & 65 & $81 \%$ \\
Se habla directo a la audiencia & 8 & $10 \%$ \\
Combinación de ambos & 7 & $9 \%$ \\
\hline
\end{tabular}

\section{CUADRON ${ }^{\circ} 5$}

\section{TRATAMIENTO DE PERSONAJES}

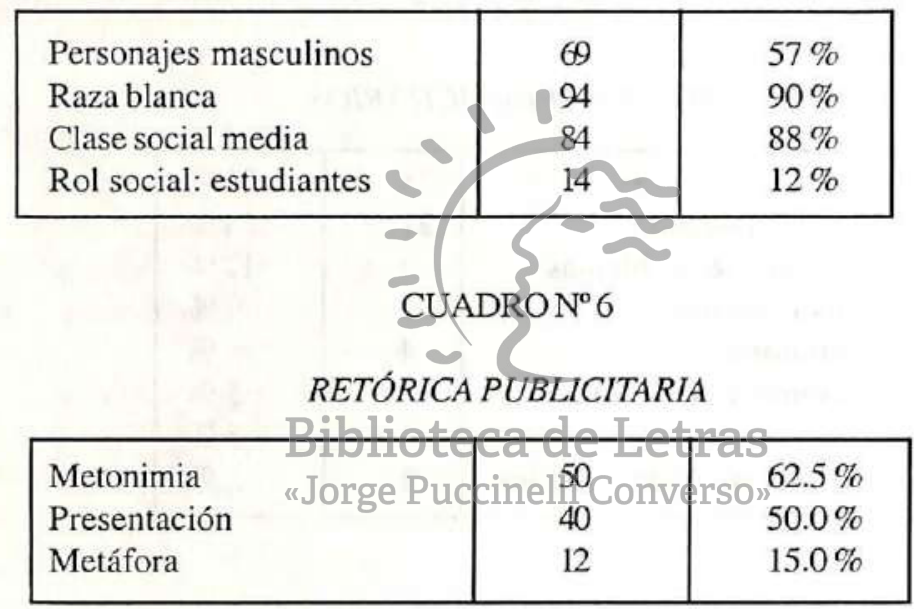

\section{Conclusiones}

1. La publicidad constituye un supersistema de medios de comunicación, paradigmático de la cultura de masas de la sociedad de la información, la cual ejerce una significativa influencia -mas no efectos todopoderosossobre las diferentes audiencias-públicos a las que se dirige.

2. La manera como influye - probada en numerosas investigaciones-la realiza a través de un eficiente sistema de investigación de mercados y de públicos, detectando las motivaciones más profundas del ser humano y usándolas para lograr la identificación con sus audiencias. 
3. Es a través de un sofisticado lenguaje y retórica, al que se unen las nuevas tecnologías de la comunicación y la información, que la publicidad hace una propuesta sumamente atractiva, impactante, reiterativa y siempre presente en la vida de las gentes. El medio principal de toda campaña y paquete publicitario es el televisivo, el cual viene participando en la creación de la llamada civilización de la imagen.

4. A través de este lenguaje y retórica se presentan normas, valores sociales y estilos de vida que respetando las exigencias de la globalización mundial y cultural mundial, encuentra acogida a nivel local, al incorporar los particularismos sociales de lo local.

5. En este sentido, la publicidad plantea como ideal de vida un consumismo radical, a través del uso de personajes caracterizados por su fuerte acentuación en lo masculino, en lo joven, en la raza blanca y clase alta, y que ejercen roles de prestigio y éxito social.

6. Para lograr lo anterior, la publicidad realiza un probado ejercicio del lenguaje propio de la televisión en lo que respecta a su gramática, explotando los recursos del color, el movimiento, la música, los efectos sonoros y electrónicos, para proponer un mundo feliz y sin conflictos.

7. El tipo de publicidad quelocupa calsi el cien porciento de los mensajes es el correspondiente a la publicidad connetativa, subjetiva, cargada de significaciones y sentidos diversos, dado por el uso de estrategias retóricas eficaces que lindan con la estética y la poesía.

8. Dado que la televisión de señal abierta, frente a la TV por cable que responde a exigencias de segmentación del público, se dirige preferentemente al público en general; la publicidad colocada en este medio tiene como blanco también el público familiar, amplio, de adultos jóvenes, a mas de casa, niños y jóvenes.

9. Los eslóganes usados por la publicidad responden a fórmulas coherentes con la naturaleza breve, sencilla, clara y susceptible de ser recordada y repetida de la publicidad televisiva, que se hace cada vez más concentrada e impactante, dada la alta inversión económica que demanda la producción y la propia naturaleza de la televisión. 
10. La motivación más importante a la que apela la publicidad en nuestro medio tiene que ver con las necesidades de realización personal, profesional y social, así como a las del prestigio social.

11. La implicación al receptor que en el sistema publicitario es un requisito ineludible, se realiza a través de un régimen mixto, de mirada directa a la cámara del presentador y la del relato, en tres cuartos o perfil.

12. Los géneros publicitarios más frecuentes son los relacionados con la demostración de beneficios, la mayoría de los cuales son ficticios, a través de presentadores famosos del medio social como de personajes anónimos, y los correspondientes al relato o historias.

13. Las tendencias generales en cuanto a gramática televisiva tienen en cuenta el uso de planos mayormente generales, primeros planos y planos medios, con los cuales se presentan escenarios grandes, así como rostros cercanos, que llaman la atención.

14. Los colores predominantes son connotativos, en lo que se refiere a los grises que transmiten mensajes de sobriedad, elegancia y formalidad, y los colores vivos, lo son respecto de los niños y jóvenes.

15. Los ángulos de cámarả, Ios móvimientos de cămara y de personajes son de tipo normal, buscando la naturalidad y perlo tanto la comodidad de la audiencia.

16. El tipo de edición es el referido al corte, con lo que se logra mensajes muy ágiles y rápidos.

17. Hay una fuerte predominancia de la locución masculina sobre la femenina, lo que reproduce simétricamente la tendencia social.

18. Los personajes son mayormente jóvenes, de sexo masculino, de raza blanca, de clase alta y con roles sociales, que también reproducen las relaciones de poder. 